\title{
pRJ5: a naturally occurring Staphylococcus aureus plasmid expressing constitutive macrolide-lincosamide-streptogramin B resistance contains a tandem duplication in the leader region of the ermC gene
}

\author{
S. S. Oliveira, ${ }^{1}$ E. Murphy, ${ }^{2}$ M. R. Gamon ${ }^{1}$ and M. C. F. Bastos ${ }^{1 *}$ \\ ${ }^{1}$ Departamento de Microbiologia Geral, Instituto de Microbiologia, CCS, Bloco I, Cidade Universitária, 21944-970, \\ Rio de Janeiro, RJ, Brazil \\ ${ }^{2}$ Department of Plasmid Biology, The Public Health Research Institute, 455 First Av., New York, NY 10016, USA
}

(Received 3 September 1992; revised 17 February 1993; accepted 3 March 1993)

\begin{abstract}
The $2.55 \mathrm{~kb}$ Staphylococcus aureus plasmid, pRJ5, confers constitutive resistance to macrolidelincosamide-streptogramin B (MLS) antibiotics. pRJ5 is nearly identical to the inducible MLS resistance plasmid pT48, and has homology with the $S$. aureus plasmids pE194 and pSN2. The HindIII-C and/or Hind-B fragments were required for stable maintenance of the plasmid and probably carry palA. Plasmids pRJ5 and pT48 were shown to belong to the same incompatibility group, Inc12 (L). DNA sequencing showed that pRJ5 contains a 28 bp direct tandem duplication in the leader/attenuator region of $\mathrm{ermC}$. This is likely to change the secondary structure of the methylase mRNA, allowing constitutive expression of ermC. The type of mutation found on plasmid pRJ5 is different from those observed in similar $2.5 \mathrm{~kb}$ constitutive MLS-resistance plasmids isolated from other Grampositive bacteria, including staphylococci.
\end{abstract}

\section{Introduction}

Resistance to macrolide-lincosamide-streptogramin B (MLS) antibiotics was encountered almost as soon as these drugs were introduced into clinical practice. The most common form of MLS resistance is caused by $\mathrm{N}^{6}, \mathrm{~N}^{6}$-dimethylation of an adenine residue in the $23 \mathrm{~S}$ ribosomal RNA, which reduces the affinity between the antibiotic and the ribosome (Dubnau, 1984). In some isolates, production of the methylase enzyme is inducible by sub-inhibitory concentrations of erythromycin (Em) or the related antibiotic oleandomycin (Dubnau, 1984) by a mechanism that involves translational attenuation. However, in many strains the expression of the methylase is constitutive (Novick et al., 1979a; Bastos et al., 1980; Lampson \& Parisi, 1986; Monod et al., 1986; Catchpole \& Dyke, 1990).

In Staphylococcus aureus, MLS resistance is commonly mediated by small $(2-4 \mathrm{~kb})$ class I multicopy plasmids (Lyon \& Skurray, 1987; Novick, 1989) of either the pE194 family or the pSN2 family. Class I plasmids replicate by a rolling circle mechanism (RCR) (Te Riele

\footnotetext{
*Author for correspondence. Tel 21270 8344; fax 212708793.
}

The nucleotide sequence data reported in this paper have been submitted to GenBank and have been assigned the accession number L04687. et al., 1986; Gruss \& Ehrlich, 1989; Novick, 1989). Three plasmid-encoded elements are used in RCR: a plus origin, a replication protein ( $\mathrm{Rep})$ and a minus origin (palA).

Plasmid pE194 encodes the ermC gene, which confers inducible MLS resistance, and it is to date the only member of its family. pE194 is $3.7 \mathrm{~kb}$ in size, and has been extensively studied in both $S$. aureus (Weisblum $e t$ al., 1979; Iordanescu \& Surdeanu, 1980; Byeon \& Weisblum, 1990; Sozhamannan et al., 1990) and Bacillus subtilis (Gryczan et al., 1980; Shivakumar et al., 1980; Horinouchi \& Weisblum, 1982).

pSN2 is a 1288 bp cryptic plasmid. Its only significant ORF encodes a protein required for initiation of plasmid replication (Khan \& Novick, 1982). The pSN2 family includes a series of closely related plasmids that contain an MLS resistance determinant linked to the basic pSN2 replicon. Those plasmids possess MLS resistance determinants which are homologous with ermC, although their replication regions do not share homology with that of pE194 (Projan et al., 1987; Catchpole et al., 1988; Catchpole \& Dyke, 1990, 1991).

In this study we present a molecular characterization of pRJ5, a plasmid from $S$. aureus that encodes MLS resistance (Bastos et al., 1980), including the DNA sequence of the ermC leader region. The sequence relations between pRJ5 and other MLS resistance 
Table 1. Bacterial strains and plasmids

\begin{tabular}{|c|c|c|c|c|}
\hline Strain & Plasmid & $\begin{array}{l}\text { Size } \\
(\mathrm{kb})\end{array}$ & $\begin{array}{l}\text { Phenotype associated } \\
\text { with plasmid* }\end{array}$ & Source or reference \\
\hline MB3 & pRJ5 & $2 \cdot 55$ & $\mathrm{MLS}^{\mathrm{r}} \mathrm{I}^{-}$ & $\begin{array}{l}\text { Bastos et al. } \\
\text { (1980); this study) }\end{array}$ \\
\hline RN1801 & pT127 & $4 \cdot 4$ & $\mathrm{Tc}^{\mathrm{r}}, \operatorname{Inc} 3(\mathrm{C})$ & Iordanescu (1976) \\
\hline RN2442 & pE194 & $3 \cdot 72$ & $\left.\mathrm{MLS}^{\mathrm{r}} \mathrm{I}^{+} \operatorname{Incl} 1 \mathrm{(K}\right)$ & Iordanescu (1976) \\
\hline SA1 105 & pE2222 & $2 \cdot 5$ & $\mathrm{MLS}^{\mathrm{r}} \mathrm{I}^{-} \operatorname{Inc12}(\mathrm{L})$ & $\begin{array}{l}\text { Iordanescu \& Surdeanu } \\
(1980)\end{array}$ \\
\hline SA1117 & pSA6522 & $7 \cdot 0$ & $\mathrm{Tc}^{\mathrm{r}}$, Inc3 Inc12 & $\begin{array}{l}\text { Iordanescu \& Surdeanu } \\
(1980)\end{array}$ \\
\hline T48 & pT48 & $2 \cdot 47$ & $\operatorname{MLS}^{\mathbf{r}} \mathrm{I}^{+}$ & Catchpole et al. (1988) \\
\hline Sk31 & pSN2 & $1 \cdot 28$ & - & Khan \& Novick (1982) \\
\hline RN451 & - & - & - & Novick (1967) \\
\hline
\end{tabular}

${ }^{*} \mathrm{I}^{+}$, inducible phenotype; $\mathrm{I}^{-}$, constitutive phenotype.

plasmids were also investigated by comparing restriction endonuclease maps and functional organization and by hybridization.

\section{Methods}

Bacterial strains, growth conditions and plasmids. $S$ aureus strains and plasmids are listed in Table 1. The strains were grown in CY medium (Novick, 1967) and stored at $-70^{\circ} \mathrm{C}$ until needed. Subcultures were made in either trypticase soy broth (TSB, Difco) or trypticase soy agar (TSA, Difco). When necessary, media were supplemented with tetracycline (Tc) and/or erythromycin (Em) at $5 \mu \mathrm{g} \mathrm{ml}^{-1}$. The cultures were incubated at $32{ }^{\circ} \mathrm{C}$.

For the analysis of plasmid stability, and for segregation analysis, exponential-phase cultures were diluted 1000 -fold and grown in TSB, in the absence of selection, until the culture had regained its original density. This was repeated 10 times. The proportion of plasmid-free cells was determined by serial dilution and plating on drug-free agar followed by replica-plating on drug-containing agar.

Plasmid transfer. Transductions with phage $\phi 11$ were done as described previously (Bastos et al., 1980). Transformation was performed as described by Murphy et al. (1981).

Plasmid DNA isolation. Whole cell lysates were prepared as described by Giambiagi-Marval et al. (1990). Plasmid DNA was prepared by caesium chloride/ethidium bromide density-gradient centrifugation of cleared lysates, prepared as described by Novick et al. $(1979 b)$.

Restriction endonuclease analysis. Restriction endonucleases were purchased from New England Biolabs and used as specified by the manufacturer.

Gel electrophoresis. Restriction endonuclease digests of plasmid DNA and uncut plasmids were analysed by electrophoresis in $0 \cdot 7-1.5 \%$ (w/v) agarose horizontal slab gels and/or in $5.0 \%(\mathrm{w} / \mathrm{v})$ polyacrylamide vertical slab gels (Sambrook et al., 1989). In both cases, both gel buffer and running buffer were $89 \mathrm{~mm}$-Tris, $89 \mathrm{~mm}$-boric acid and $2.5 \mathrm{~mm}$-EDTA. Size standards for linear DNA fragments were bacteriophage $\lambda$ DNA cleaved with BstEII or with HindIII and EcoRI and bacteriophage $\phi$ X174 DNA cleaved with HaeIII (Ausubel et al., 1990).

DNA hybridization. Southern blot hybridization was done as described previously (Bastos \& Murphy, 1988). Probe DNA was labelled by nick-translation as described by Sambrook et al. (1989).
PCR cloning and sequencing. Primers corresponding to nucleotides 1616-1634 and 1889-1917 of pT48 were used to amplify a fragment from plasmid pRJ5, equivalent to a $301 \mathrm{bp}$ fragment of pT48, that included the region encoding the leader peptide and the $5^{\prime}$ part of ermC. To prepare template DNA, cells from strain MB3 were scraped with a toothpick from a TSA plate incubated for $18 \mathrm{~h}$, washed twice in $10 \mathrm{mM}$ Tris, $0.1 \mathrm{~mm}$-EDTA, pH 7.8, resuspended in $200 \mu \mathrm{l}$ of the same buffer, and lysed by the addition of $100 \mu \mathrm{g}$ lysostaphin $\mathrm{ml}^{-1}$. After incubation for $30 \mathrm{~min}$, lysis was completed by the addition of SDS to a final concentration of $0.2 \%$. Two microlitres of this preparation was used for PCR.

PCR reactions used Vent polymerase (New England Biolabs) in a reaction mixture containing each primer at $100 \mu \mathrm{M}$ and other components as specified by the manufacturer. Reactions were cycled at $94^{\circ} \mathrm{C}$ for $1 \mathrm{~min}, 45^{\circ} \mathrm{C}$ for $45 \mathrm{~s}$ and $72^{\circ} \mathrm{C}$ for $45 \mathrm{~s}$, for 25 cycles. A fragment of approximately $325 \mathrm{bp}$ was purified by electrophoresis on a $3 \%(\mathrm{w} / \mathrm{v})$ NuSieve gel (FMC Bio Products). The excised band was melted at $65^{\circ} \mathrm{C}$ and incubated without further purification with T4 DNA-ligase and SmaI-cleaved M13mp11 RF1 DNA. The ligation mixture was used to transform Escherichia coli JM109. Six clones, all with inserts in the same orientation, were sequenced by the dideoxynucleotide chain termination method (Sanger et al., 1977), using Sequenase (US Biochemicals) and $\left[\alpha^{35}\right.$ S $]$ dATP (New England Nuclear).

Computer analysis. Possible RNA secondary structures were predicted by the computer program of Zuker \& Stiegler (1981).

\section{Results and Discussion}

Structural organization of $p R J 5$ and its relationship to other $S$. aureus plasmids

A restriction map of $p R J 5$ is presented in Fig. 1. The homology between pRJ5 DNA and pE194 or pSN2 was investigated by Southern hybridization, using pE194 and pSN2 as probes (Fig. 1). The size of pRJ5 was estimated as $2.55 \mathrm{~kb}$. pRJ5 contains a $1.35 \mathrm{~kb}$ region homologous to $\mathrm{pE} 194$ located between positions 910 and 2260 . A comparison of the restriction maps of $\mathrm{pRJ} 5$ and $\mathrm{pE} 194$ (Fig. 1) indicates that some of the restriction sites in the region of homology between these plasmids are conserved. This region includes the ermC gene, encoding a 23S rRNA methylase, and the leader region that controls 


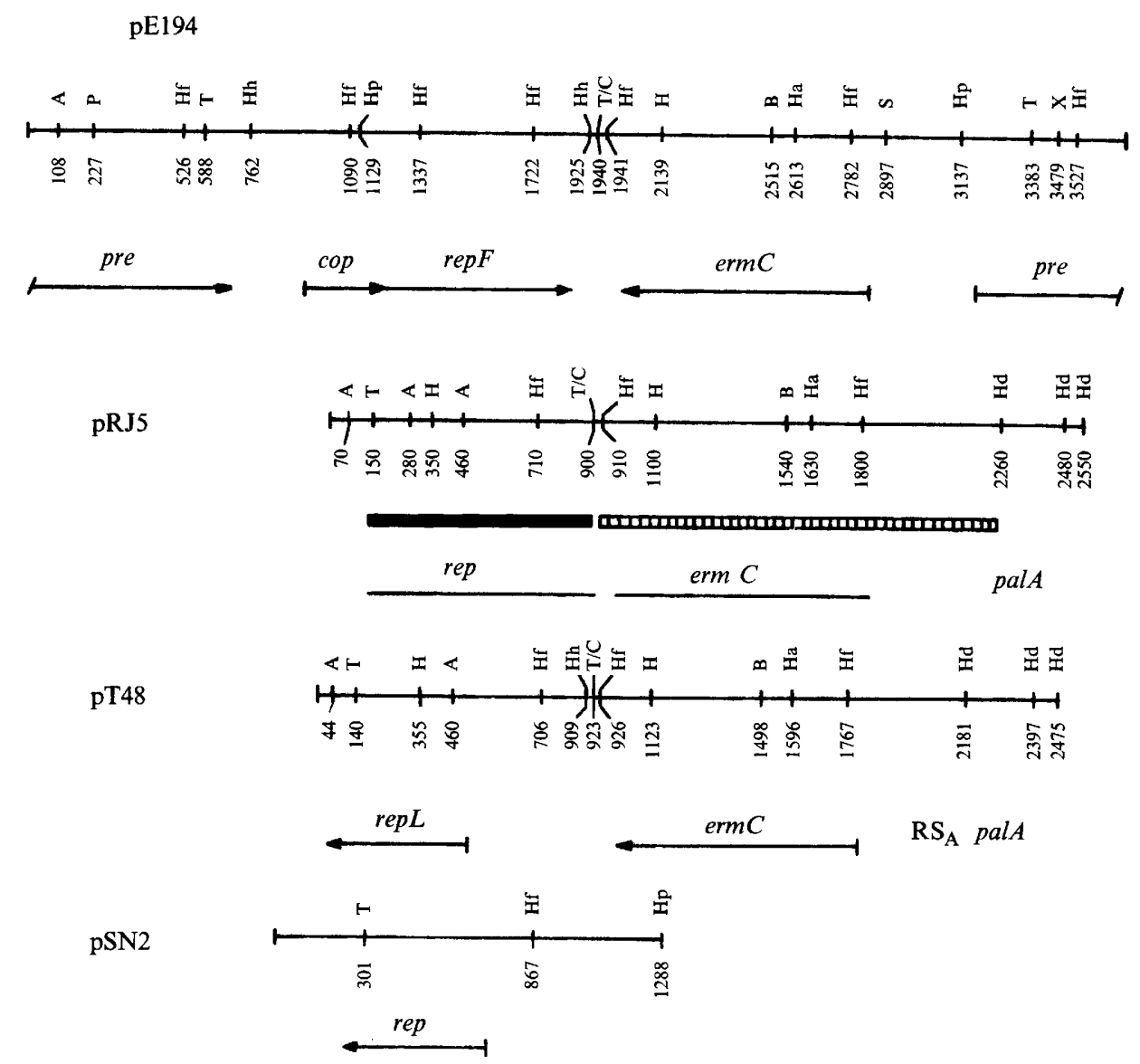

Fig. 1. Comparative analysis of the restriction maps and the functional organization of the plasmids pE194 (Horinouchi $\&$ Weisblum, 1982; Byeon \& Weisblum, 1990), pRJ5, pT48 (Catchpole et al., 1988) and pSN2 (Khan \& Novick, 1982). The plasmids are linearized to emphasize the alignment of homologous regions. Relevant restriction sites are indicated as follows: A, AccI; B, BclI; C, ClaI; H, HpaI; Hp, HpaII; Ha, HaeIII; Hh, HhaI; Hd, HindIII; Hf, HinfI; P, PstI, S, SacI; T, TaqI ; X, XbaI. For plasmids pE194, pT48 and pSN2, the nucleotide positions are from the DNA sequence. Numbering starts from a MboI site for pE194, from a HindIII site for pRJ5 and pT48 and from a HpaII site for pSN2. ORFs are designated by arrows. pre, plasmid recombination protein; cop, copy number control; rep, replication protein; erm, methylase; palA, minus-strand conversion signal; $\mathbf{R S}_{\mathrm{A}}$, recombination site $\mathrm{A}$. The presumed locations of ermC, rep and palA are shown for $\mathrm{pRJ}$. The solid bar indicates the pSN2 homologous region and the cross-hatched bar indicates the pE194 homologous region in pRJ5.

its expression. We conclude that the MLS resistance determinant of $\mathrm{pRJ} 5$ is very similar to $\mathrm{erm} C$, and that the remainder of $\mathrm{pRJ} 5$ bears no detectable homology with $\mathrm{pE} 194$. Therefore, $\mathrm{pRJ} 5$ cannot be placed in the pE194 family of class I plasmids.

pRJ5 also showed homology to plasmid pSN2, between positions 150 and 900 . This homology corresponds, in $\mathrm{pSN} 2$, to the region encoding RepL, the protein involved in initiation of plasmid replication (Khan \& Novick, 1982; Novick, 1989). Based on these results, pRJ5 can be placed in the pSN2 family of class I plasmids.

The restriction map of pRJ5 is nearly identical to that of pT48 (Fig. 1), which also belongs to the pSN2 family (Catchpole et al., 1988). The HindIII-B fragment of pT48 encloses most of palA, an imperfect palindrome of about 156 bp (Catchpole et al., 1988). If the HindIII-B fragment of $\mathrm{pRJ} 5$ also contains palA sequences, the removal of this fragment would generate plasmid instability. palA mutants of $S$. aureus plasmids have a marked decrease in copy number and are highly unstable (Gruss et al., 1987). To delete the small HindIII fragments B and C, pRJ5 DNA was completely digested with HindIII, religated, and used to transform protoplasts of strain RN451 with selection for $\mathrm{Em}^{\mathrm{R}}$. The transformants were analysed for the presence of plasmid DNA, which was barely visible in agarose gels (data not shown), indicating that the copy number was low. The deletion derivatives were also highly unstable, being lost from $94 \%$ of cells after approximately 50 generations in the absence of selection. Plasmid DNA from some deletion derivatives was transferred to nitrocellulose and hybridized to ${ }^{32} \mathrm{P}$-labelled pRJ5 DNA. Multimeric forms of pRJ5, mainly dimers, were detected (data not 
Table 2. Incompatibility between $p R J 5, p T 48$ and pSA6522

The phenotype associated with each plasmid is shown in Table 1 . At least 2 transductants from each cross were subjected to segregation analysis by growth at $32^{\circ} \mathrm{C}$ for about 100 generations under nonselective conditions. Strain RN451 was used as the host strain. Each plasmid was shown to be stable in RN451.

\begin{tabular}{lllcr}
\hline & & & \multicolumn{2}{c}{ Colonies resistant to } \\
\cline { 4 - 5 } $\begin{array}{l}\text { Donor } \\
\text { plasmid }\end{array}$ & $\begin{array}{l}\text { Resident } \\
\text { plasmid }\end{array}$ & $\begin{array}{l}\text { Colonies } \\
\text { tested }\end{array}$ & Em & Tc \\
\hline pSA6522 & pRJ5 & 1118 & $18(1.61 \%)$ & $1113(99 \cdot 55 \%)$ \\
pSA6522 & pT48 & 174 & 0 & $174(100 \%)$ \\
pSA6522 & pE2222 & 358 & $69(19 \cdot 27 \%)$ & $358(100 \%)$ \\
pT127 & pRJ5 & 1977 & $1947(98.48 \%)$ & $1975(99.9 \%)$ \\
\hline \hline
\end{tabular}

shown). These data confirm our assumption that pRJ5 is similar to pT48, and that the HindIII-C and/or HindIII-B fragments of pRJ5 encompass at least part of a palA-like sequence.

Incompatibility relationship between plasmids $p R J 5$ and pT48

At least 14 distinct incompatibility (Inc) groups have been defined for plasmids of $S$. aureus (Novick, 1989). We tested the relationships of pRJ5 and pT48 with other $S$. aureus plasmids.

So far, plasmids $\mathrm{pE} 12$ and pIM13 were the only members of the pSN2 family whose Inc group has been determined. They were assigned to the Inc12 (1) group (Novick, 1989); this group was therefore tested first. Plasmid pE2222 is a representative member of this group and it also encodes $\mathrm{Em}^{\mathrm{R}}$ (Iordanescu \& Surdeanu, 1980). However, the family of this plasmid had not yet been determined. Since pE2222, pRJ5 and pT48 carry the same resistance marker $\left(\mathrm{Em}^{\mathrm{R}}\right)$, the Inc relationships between them were studied using a recombinant plasmid (pSA6522) formed between pE2222 (with a mutation in the erm gene) and pSA0301 (a $\mathrm{Tc}^{\mathrm{R}}$ plasmid that belongs to group Inc 3).

Heteroplasmid strains carrying plasmid pT127 and pRJ5 were stably inherited which demonstrated that pRJ5 is compatible with plasmids from the Inc3 (C) group (Table 2). Heteroplasmid clones carrying plasmids pSA6522 and pE2222 were used to confirm that the Inc12 system was still functional in the recombinant plasmid pSA6522.

Heteroplasmid clones were constructed by transduction of pSA6522 into the host strains carrying either pRJ5 or pT48, with selection for resistance to Tc and Em. In each cross, at least two transductants were tested for plasmid segregation. Plasmid pSA6522 could efficiently displace both pRJ5 and pT48 (Table 2). These results were confirmed by agarose gel electrophoresis of plasmid DNA isolated from 20 colonies resistant to either Tc or Em (data not shown). It can be concluded that pE2222, pRJ5 and pT48 are mutually incompatible and therefore belong to Inc12. This also confirms the close relationship between pRJ5 and pT48 and suggests that pRJ5 and pE2222 belong to the pSN2 family.

\section{Incompatibility relationship between pRJ5 and pSN2}

Plasmid pRJ5 was transduced into strain SK31, which carries the cryptic plasmid pSN2, with selection for $\mathrm{Em}^{\mathrm{R}}$. Two transductants were subjected to segregation analysis as described above. After about 100 generations of growth, each of the 673 colonies tested after plating on drug-free agar were $\mathrm{Em}^{\mathrm{R}}$. Forty colonies were screened for plasmids by agarose gel electrophoresis and all of them contained both plasmids pRJ5 and pSN2 (data not
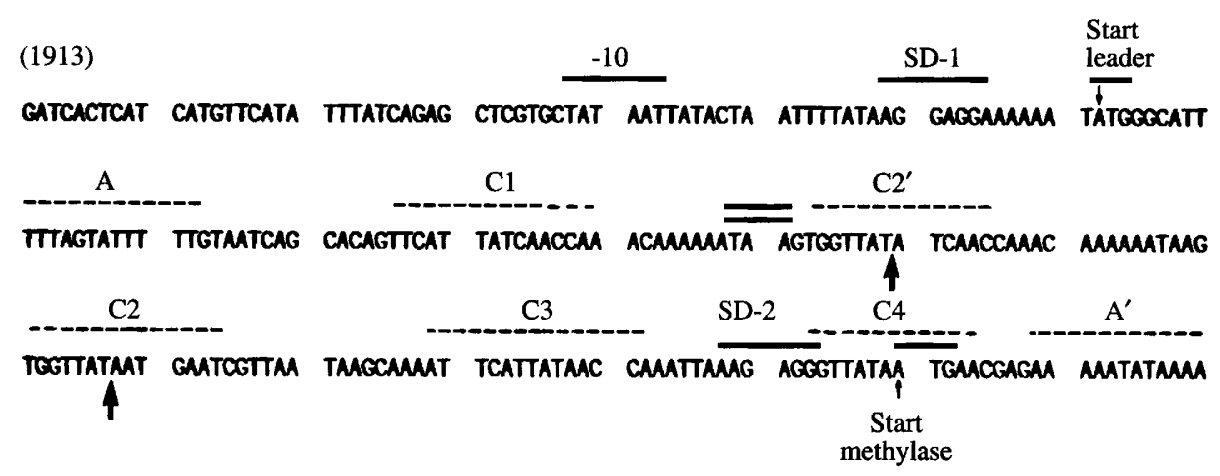

CACAGTCMA ACTTTATTAC TTCMMACAT MTATAGATA MA

(1659)

Fig. 2. Nucleotide sequence of the erm C control region from pRJ5. The $283 \mathrm{bp}$ sequence from a $M b o \mathrm{I}$ site of pRJ5 shows the control region for ermC and the $5^{\prime}$ end of the methylase gene. Structures labelled A, $\mathbf{A}^{\prime}, \mathrm{C} 1, \mathrm{C} 2, \mathrm{C} 2{ }^{\prime}, \mathrm{C} 3$ and $\mathrm{C} 4$ represent repeat sequences. $\mathrm{SD}$ indicates a Shine-Dalgarno sequence. The termination codon for the putative leader peptide is indicated by double bars. The arrows indicate the beginning and the end of a $28 \mathrm{bp}$ tandem duplication found in pRJ5. Positions are numbered with respect to pT48 sequence. 
(a)

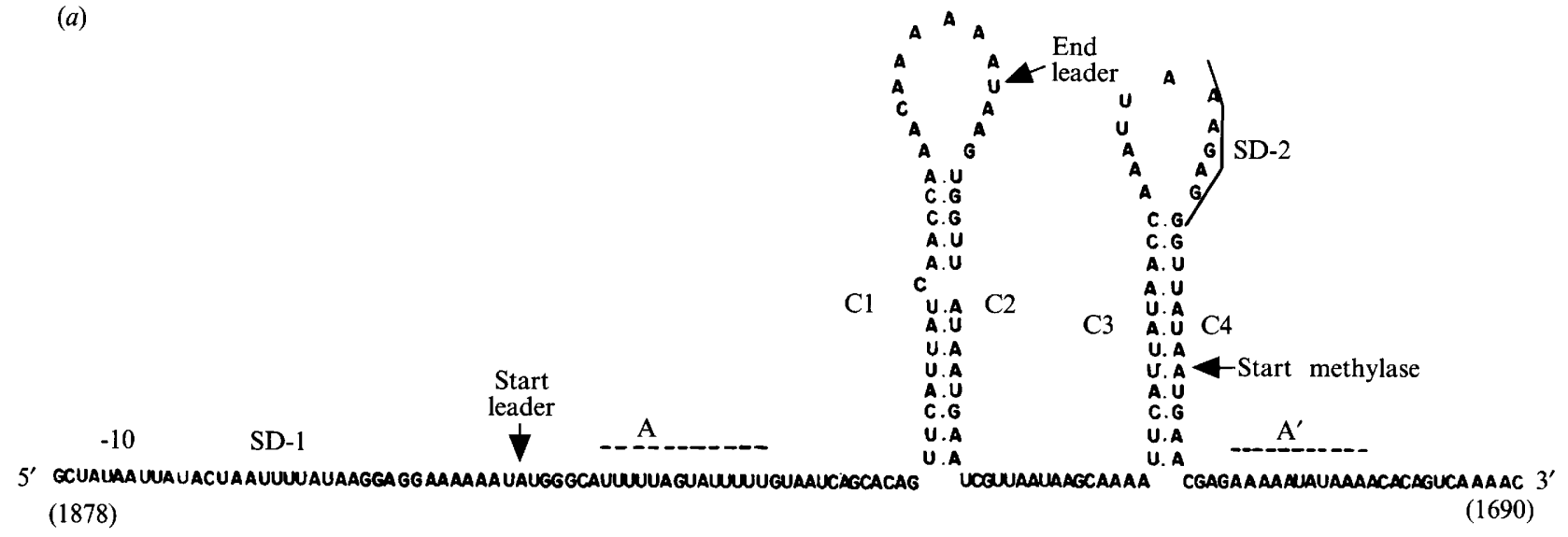

(b)

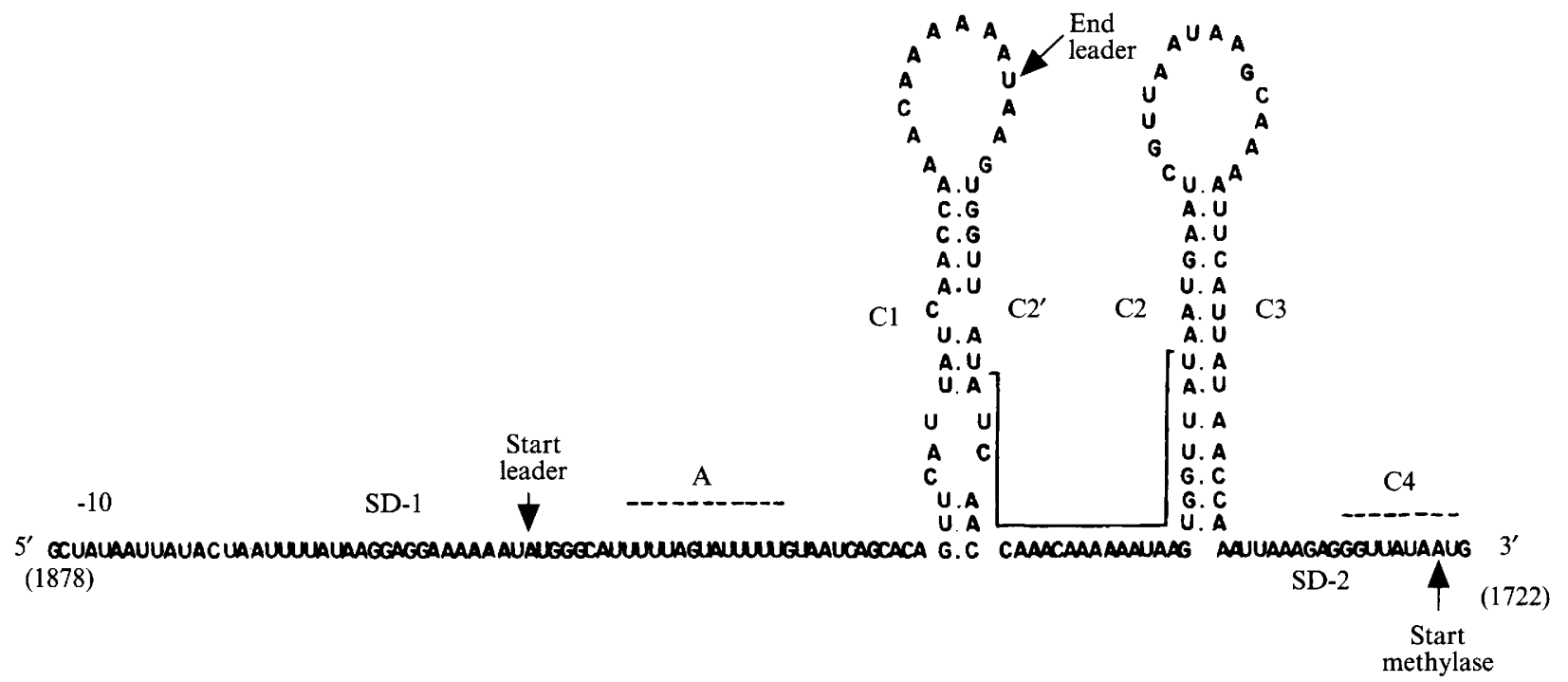

Fig. 3. (a) A predicted inactive conformation of the ermC leader region in pT48 (Catchpole et al., 1988). (b) A possible change in the conformation of the erm $C$ regulatory region due to a 28 bp direct tandem duplication in pRJ5. A, A', C1, C2, C2', C3 and C4 are repeat sequences. SD-1 and SD-2 are the Shine-Dalgarno sequences for the leader peptide and the methylase, respectively. Heavy lines above the sequence indicate the tandem duplication found in pRJ5. Numbers are nucleotide coordinates according to the published sequence for pT48 (Catchpole et al., 1988).

shown). Thus pRJ5 coexists stably with pSN2 without selection, and therefore these plasmids belong to distinct Inc groups. According to Dr K. G. H. Dyke (personal communication), pT48 is also compatible with pSN2.

Molecular basis for the constitutive expression of the ermC gene from plasmid $p R J 5$

The restriction map of pRJ5 is nearly identical to that of pT48. However, pRJ5 confers constitutive MLS resistance, whereas pT48 confers inducible resistance. To determine the molecular basis for this difference, a small fragment of $\mathrm{pRJ} 5$, including the leader peptide and the 5 -terminus of ermC, was cloned into M13mpll and its DNA sequence was determined (Fig. 2). A comparison with the equivalent region of plasmid pT48 (Catchpole $e t$ $a l ., 1988)$ showed that a 28 bp direct tandem duplication occurred in plasmid pRJ5, beginning at nucleotide 1775 with respect to $\mathrm{pT} 48$ sequence.

A model for the inducible expression of MLS resistance was proposed by Gryczan et al. (1980) and Horinouchi \& Weisblum (1980), based on studies performed with the ermC gene from plasmid $\mathrm{pE} 194$. The ermC gene from pT48 is almost identical to ermC from 
pE194 (99\% base identities) (Catchpole et al., 1988). The model proposes that a $141 \mathrm{bp}$ leader region at the $5^{\prime}$ end of the ermC mRNA is capable of folding to form a secondary hairpin structure. This structure forms a translational attenuator by sequestering the ribosome binding site (SD-2) and the initiation codon (AUG) for the methylase, thus preventing full expression of MLS resistance. In addition, the $5^{\prime}$ controlling region contains a small ORF capable of encoding a 19 amino acid peptide. It is believed that induction occurs when Emsensitive ribosomes, in the process of translating the small leader peptide, become stalled due to the inhibiting effect of Em. This precipitates a change in the secondary structure of the mRNA to a conformation in which the initiation signals SD-2 and AUG become unpaired. The mRNA is now accessible to ribosomes, which initiate translation of the methylase gene.

The model described above is supported by the properties of both regulatory mutations and naturally occurring plasmids which confer constitutive MLS resistance. Several changes which result in constitutive expression have been identified among mutants of pE194. A point mutation in the repeat sequence $\mathrm{C} 3$ disrupted its ability to form a stem-loop structure with repeat sequence C4, thus freeing SD-2 (Gryczan et al., 1980; Horinouchi \& Weisblum, 1980). Duplication of repeat segments $\mathrm{C} 3$ and $\mathrm{C} 4$ ensures that one set of initiation signals is always unpaired (Gryczan et al., 1980). A third type of constitutive mutant involves deletions of the leader peptide region (Hahn et al., 1982). However, in naturally occurring plasmids conferring constitutive MLS resistance, only deletions affecting the leader peptide gene repeats $\mathrm{C} 1$ and $\mathrm{C} 2$ have been reported.

Analysis of the DNA sequence of the constitutive MLS resistance determinants from plasmids pNE131 (Lampson \& Parisi, 1986), pIM13 (Monod et al., 1986), pJ74 (Catchpole et al., 1988) and pA22 (Catchpole \& Dyke, 1990) revealed deletions of $107 \mathrm{bp}, 107 \mathrm{bp}, 71 \mathrm{bp}$ and $58 \mathrm{bp}$, respectively, in the leader/attenuator region. Since the only difference found between pRJ5 and pT48 in this region is a $28 \mathrm{bp}$ direct tandem duplication, we assume that this is the cause of the constitutive phenotype conferred by pRJ5.

According to the translational attenuation model for regulation of MLS resistance, the tandem duplication in pRJ5 should result in an alternate conformation of the mRNA, allowing constitutive expression of the methylase. The predicted folding of the ermC leader region for plasmid pT48 in the uninduced state is shown in Fig. 3(a) (Catchpole et al., 1988). Only SD-1 is accessible to ribosomes, so only the leader peptide is translated. SD-2 is sequestered within an energetically favourable base-paired structure, and methylase is not expressed. In $\mathrm{pRJ} 5$, the tandem duplication should permit the formation of a structure similar to that in Fig. $3(a)$, but in which SD-2 and the associated AUG codon are exposed. Fig. 3(b) shows one such structure. The direct tandem duplication found in pRJ5 provides an extra sequence, designated $\mathrm{C}^{\prime}$, which if paired to $\mathrm{C} 1$, would form a hairpin with a very low stability $(\Delta G=-7.5 \mathrm{kcal})$ compared to the hairpin formed by $\mathrm{Cl}$ and $\mathrm{C} 2$ in pT48 $(\Delta G=-13.9 \mathrm{kcal})$. This structure is probably not formed in vivo. Thus the primary effect of the duplication would be to destabilize pairing of $\mathrm{C} 1$ and $\mathrm{C} 2$. Consequently, $\mathrm{C} 2$ would pair with $\mathrm{C} 3$, forming a stable hairpin $(\Delta G=-18.5 \mathrm{kcal})$ which would release $\mathrm{C} 4$ and make the expression of MLS resistance constitutive. This hairpin has a higher stability than that formed by $\mathrm{C} 3$ and C4 in pT48 $(\Delta G=-16.9 \mathrm{kcal})$.

The stable $\mathrm{C} 2-\mathrm{C} 3$ pairing proposed for plasmid $\mathrm{pRJ} 5$, including only the second hairpin, is identical to structures proposed for plasmids pJ74, pNE131, pIM13 and pA22 (Catchpole \& Dyke, 1990) and is in agreement with Gryczan et al. (1980), Horinouchi \& Weisblum (1980) and Mayford \& Weisblum (1989), who postulated that disruption of the integrity of $\mathrm{C} 3$ plus $\mathrm{C} 4$ to free sequence SD-2 constitutes the key event in induction of the ermC transcript.

In conclusion, it is suggested that the tandem duplication is responsible for the constitutive MLS resistance specified by pRJ5. This report shows that pRJ5 differs from all other constitutive MLS resistance plasmids, and shows that several different mutations have occurred in natural isolates.

We could like to thank Dr Saleem Khan, Dr Serban Iordanescu and Dr K. G. H. Dyke for providing strains. This work was supported by grants from CNPq (Brazil) to M.C.F.B.

\section{References}

Ausubel, F. M., Brent, R., Kingston, R. E., Moore, D. D., Seidman, J. G., Smith, J. A. \& StruHL, K. (1990). Current Protocols in Molecular Biology. New York: John Wiley and Sons.

Bastos, M. C. F. \& MuRPhy, E. (1988). Transposon Tn554 encodes three products required for transposition. EMBO Journal 7, 2935-2941.

Bastos, M. C. F., Bonaldo, M. C. \& Penido, E. G. C. (1980). Constitutive erythromycin resistance plasmid in Staphylococcus aureus. Journal of General Microbiology 121, 513-516.

ByeON, W.-H. \& WeisBlum, B. (1990). Replication genes of plasmid $\mathrm{pE194-cop}$ and repF: transcripts and encoded proteins. Journal of Bacteriology 172, 5892-5900.

CATChPOle, I. \& DyKe, K. G. H. (1990). A Staphylococcus aureus plasmid that specifies constitutive macrolide-lincosamidestreptogramin B resistance contains a novel deletion in the ermC attenuator. FEMS Microbiology Letters 69, 43-48.

Catchpole, I. \& DYKe, K. G. H. (1991). Replication mutants of Staphylococcus aureus macrolide-lincosamide-streptogramin B resistance plasmid pT48. Molecular Microbiology 5, 959-968.

Catchrole, I., Thomas, C., Davies, A. \& Dyke, K. G. H. (1988). The nucleotide sequence of Staphylococcus aureus plasmid pT48 conferring inducible macrolide-lincosamide-streptogramin B resistance and comparison with similar plasmids expressing constitutive resistance. Journal of General Microbiology 134, 697-709. 
DuBnaU, D. (1984). Translational attenuation: the regulation of bacterial resistance to the macrolide-regulation of bacterial resistance to the macrolide-lincosamide-streptogramin B antibiotics. CRC Critical Reviews in Biochemistry 16, 103-132.

Giambiagi-Marval, M., Mafra, M. A., Penido, E. G. C. \& Bastos, M. C. F. (1990). Distinct groups of plasmids correlated with bacteriocin production in Staphylococcus aureus. Journal of General Microbiology 136, 1591-1599.

Gruss, A. \& EHRLICH, S. D. (1989). The family of highly interrelated single-stranded deoxyribonucleic acid plasmids. Microbiological Reviews 53, 231-241.

Gruss, A., Ross, H. \& Novick, R. P. (1989). Functional analysis of a palindromic sequence required for normal replication of several staphylococcal plasmids. Proceedings of the National Academy of Sciences of the United States of America 84, 2165-2169.

Gryczan, T., Grandi, G., Hahn, J., Grandi, R. \& Dubnau, D. (1980). Conformational alteration of mRNA structure and the posttranscriptional regulation of erythromycin-induced drug resistance. Nucleic Acids Research 8, 6081-6097.

Hahn, J., Grandi, G., Gryczan, T. \& Dubnau, D. (1982). Translational attenuation of ermC: a deletion analysis. Molecular and General Genetics 186, 204-216.

Horinouchi, S. \& WeISBLum, B. (1980). Post-transcriptional modification of mRNA conformation: mechanisms that regulate erythromycin-induced resistance. Proceedings of the National Academy of Sciences of the United States of America, 77, 7079-7083.

HoriNouchi, S. \& Weislum, B. (1982). Nucleotide sequence and functional map of $\mathrm{pE194}$, a plasmid that specifies inducible resistance to macrolide, lincosamide and streptogramin-type B antibiotics. Journal of Bacteriology 150, 804-814.

IORDANESCU, S. (1976). Three distinct plasmids originating in the same Staphylococcus aureus strain. Archives of Roumanian Experimental Pathology and Microbiology 35, 111-118.

IORDANESCU, S. \& SURDEANU, M. (1980). New incompatibility groups for Staphylococcus aureus plasmids. Plasmid 4, 256-260.

KHAN, S. \& NovicK, R. P. (1982). Structural analysis of plasmid pSN2 in Staphylococcus aureus: no involvement in enterotoxin B production. Journal of Bacteriology 149, 642-649.

LAMPsON, B. \& PARISI, J. (1986). Naturally occurring Staphylococcus epidermidis plasmid expressing constitutive macrolide-lincosamidestreptogramin B resistance contains a deleted attenuator. Journal of Bacteriology 166, 479-483.

LYON, B. R. \& SKuRRAY, R. (1987). Antimicrobial resistance of Staphylococcus aureus: genetic basis. Microbiological Reviews 51, 88-134.

MAYFoRd, M. \& Weisblum, B. (1989). Conformation alterations in the ermC transcript in vivo during induction. EMBO Journal 8 , $4307-4314$.
Monod, M., Denoya, C. \& Dubnau, D. (1986). Sequence and properties of pIM13, a macrolide-lincosamide-streptogramin B resistance plasmid from Bacillus subtilis. Journal of Bacteriology 167, 138-147.

Murphy, E., Phillips, S., Edelman, I. \& Novick, R. P. (1981). Tn554: isolation and characterization of plasmid insertions. Plasmid $\mathbf{5}$, 292-305.

Novick, R. P. (1967). Properties of a cryptic high-frequency transducing phage in Staphylococcus aureus. Virology 33, 155-166.

Novick, R. P. (1989). Staphylococcal plasmids and their replication. Annual Reviews of Microbiology 43, 537-565.

Novick, R. P., Edelman, I., Schwesinger, M., Gruss, A., Swanson, E. \& Pattee, P. (1979a). Genetic translocation in Staphylococcus aureus. Proceedings of the National Academy of Sciences of the United States of America 76, 400-404.

Novick, R. P., Murphy, E., Gryczan, T. J., Baron, E. \& Edelman, I. $(1979 b)$. Penicillinase plasmids of Staphylococcus aureus: restriction-deletion maps. Plasmid 2, 109-129.

Projan, S., Monod, M., Narayanan, C. \& Dubnau, D. (1987). Replication properties of pIM13, a naturally occurring plasmid found in Bacillus subtilis, and of its close relative pE5, a plasmid native to Staphylococcus aureus. Journal of Bacteriology 169, 5131-5139.

SambrooK, J., Fritsch, E. F. \& Maniatis, T. (1989). Molecular Cloning: a Laboratory Manual. Cold Spring Harbor, NY: Cold Spring Harbor Laboratory.

SANGER, F., Nicklen, S. \& Coulson, A. (1977). DNA sequencing with chain-terminating inhibitors. Proceedings of the National Academy of Sciences of the United States of America 74, 5463-5467.

ShivaKumar, A. G., Hahn, J., Grandi, G., Kozlov, Y. \& Dubnau, D. (1980). Posttranscript regulation of an erythromycin resistance protein specified by plasmid $\mathrm{pE} 194$. Proceedings of the National Academy of Sciences of the United States of America 77, 3903-3907.

Sozhamannan, S., Dabert, P., Moretto, V., Ehrlich, S. D. \& Gruss, A. (1990). Plus-origin mapping of single-stranded DNA plasmid pE194 and nick site homologies with other plasmids. Journal of Bacteriology 172, 4543-4548.

Te Riele, H., Michel, B. \& Ehrlich, S. D. (1986). Single-stranded plasmid DNA in Bacillus subtilis and Staphylococcus aureus. Proceedings of the National Academy of Sciences of the United States of America 83, 2541-2545.

Weisblum, B., Graham, M., Gryczan, T. \& Dubnau, D. (1979). Plasmid copy number control: isolation and characterization of high copy number mutants of plasmid pE194. Journal of Bacteriology 137, 635-643.

Zuker, M. \& STIEGLeR, P. (1981). Optimal computer folding of large RNA sequences using thermodynamics and auxiliary information. Nucleic Acids Research 9, 133-148. 